\title{
TO STUDY ASPECTS OF DEGRADATION IN EDUCATIONAL PERFORMANCE OF UG STUDENTS BASED ON STATISTICAL TOOLS AND TECHNIQUES
}

\author{
Prakash S. Chougule ${ }^{1}$ \\ ${ }^{1}$ Associate Professor, Rajarshi Chhatrapati Shahu College,Kolhapur(MS) ,India,
}

Tejaswi S.Kurane ${ }^{2}$

${ }^{2}$ Assistant Professor, Rajarshi Chhatrapati Shahu College,Kolhapur(MS) ,India

\author{
S. V.Patil ${ }^{3}$
}

${ }^{3}$ Associate Professor, Rajarshi Chhatrapati Shahu College,Kolhapur(MS) ,India

\section{DattatrayD.Balip ${ }^{4}$}

${ }^{4}$ Research Student, Rajarshi Chhatrapati Shahu College,Kolhapur(MS) ,India

\section{Desai Rutuja M. ${ }^{5}$}

5Research Student, Rajarshi Chhatrapati Shahu College,Kolhapur(MS) ,India

\section{Vinayak M .Sable ${ }^{6}$}

6Research Student, Rajarshi Chhatrapati Shahu College,Kolhapur(MS) ,India

\section{JyotiT.Sutar ${ }^{7}$}

${ }^{7}$ Research Student, Rajarshi Chhatrapati Shahu College,Kolhapur(MS) ,India

\section{ABSTRACT}

Identifying the factors that influence academic performance is an essential part of educational research. Here, we study the academic performance among a selected of 349 undergraduate students from different colleges in Kolhapur district. Our work is based on primary data collected using well designed questionnaires containing various attributes. Different statistical tools and techniques are used for anaysed different aspects of degradation in students educational performance. our study shows that teacher performance is excellent and all students are satisfies with quality of teaching.

KEYWORDS: Graphical Representation, Z- Test, Chisquare Test,ANOVA, Level of significance. 


\section{INTRODUCTION}

Since research on academic achievement began to emerge as a field in the 1960s, it has guided educational policies on admissions and dropout prevention Kassarnig et al. (2018). Although more discussion made in the literature has focused on higher education, the knowledge obtained on behavioral phenomena observed in colleges and universities can potentially guide research on student behavior in primary and secondary schools and A number of behavioral patterns have been linked to academic performance, such as time allocation Macan TH et .al (1990), active social ties Gašević D (201스), sleep duration and sleep quality Curcio G et.al (2006), or participation in sport activity Singh A et.al (2012). Most of the existing studies, however, suffer from biases and limitations often associated with surveys and self-reports Van de Mortel TF et al. (2008) and Junco R (2013) ([6, 7), particularly when measuring social networks Kumbasar et.al.( 1994) ,O'Connor KM(2015) Freeman LC (1992). Today we

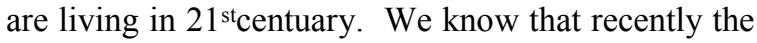
competition is increased in every field of life. Therefore the students should get the ability to compitize the world. We know that every year 6.8 crores students complete their graduation in India. But how many of them are getting a good settled life is a more important question.

Here we introduced the student's marks with their standards like $10^{\text {th }}, 12^{\text {th }}$, F.Y, S.Y, T.Y in Science faculty. We can check how their study is related to their marks and how do the students get continued their performance from, $10^{\text {th }}$ to second year. All these things of consistency in their marks should benefit to get the job. So this project gives an idea to us about the marks study combination of students.

In this article we studied the comparative academic results of third year students in different colleges. It is a view that how the students' results are correlated with their sex, facilities, teacher performance, annual income, use of social media. If we overlook all these we know that third year is most important year. So in this article the marks of third year students and how their educational graph is changed from $10^{\text {th }}$ standard to third year is increased or decreased or remains constant. So we have introduced a performance detected by the students or how it is correlated with their previous marks. That is why our study is very helpful to conclude that how their marks are continued with the standard.

In different colleges 349 students of third year are studied, in which we take 349 students to study their results. We have collected their data by taking questionnaire.

\section{OBJECTIVES}

1. To study consistency in marks of college students

2. To fit regression equation for S.Y.B. Sc. Marks of students by taking F. Y.B. Sc., H.S.C. \& S.S.C. marks as an independent variable.

\section{METHODOLOGY}

For collection of data we use questionnaire and the questionnaire includes the information about their address, use of phone, marks, parent occupation and annual income, family, use of social media, future planning, college facilities and also their view about teachers' performance. We collect information of 349 students from T.Y. B.Sc. in different colleges-

69 students from D.M. Bidri, 59 students from S.M.M. Murgud, 135 students from Vivekanand College, 31 students from the New College and 55 students from R.C. Shahu College,Kolhapur .

\section{Data Collection}

For the study we have collected primary data from Science students in following colleges by using questionnaires method.D.M. Bidri,S.M.M. Murgud,Vivekanand College, The New College,R.C. Shahu College,Kolhapur.

\section{Statistical tools used}

$>$ Graphical representation

$>$ Theory of attribute

$>$ Testing of hypothesis

\section{Software used}

- Minitab

- MS-Excel 
EPRA International Journal of Socio-Economic and Environmental Outlook (SEEO)

ISSN: 2348-4101

Volume: 7 | Issue: 4| November 2020 | SJIF Impact Factor (2020): 7.005 | Journal DOI: 10.36713/epra0314 | Peer-Reviewed Journal

\section{GRAPHICAL REPRESENTATION}

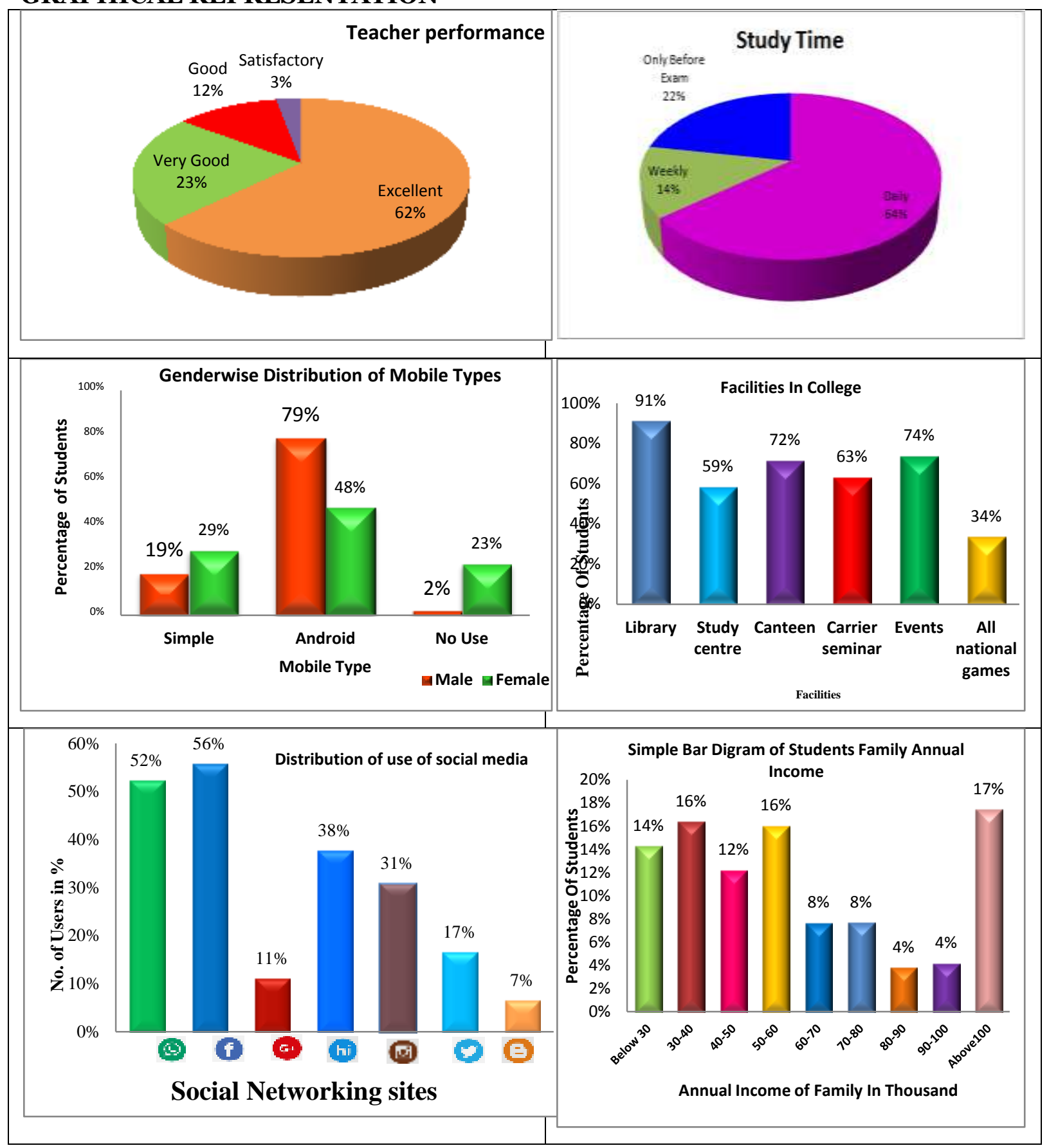




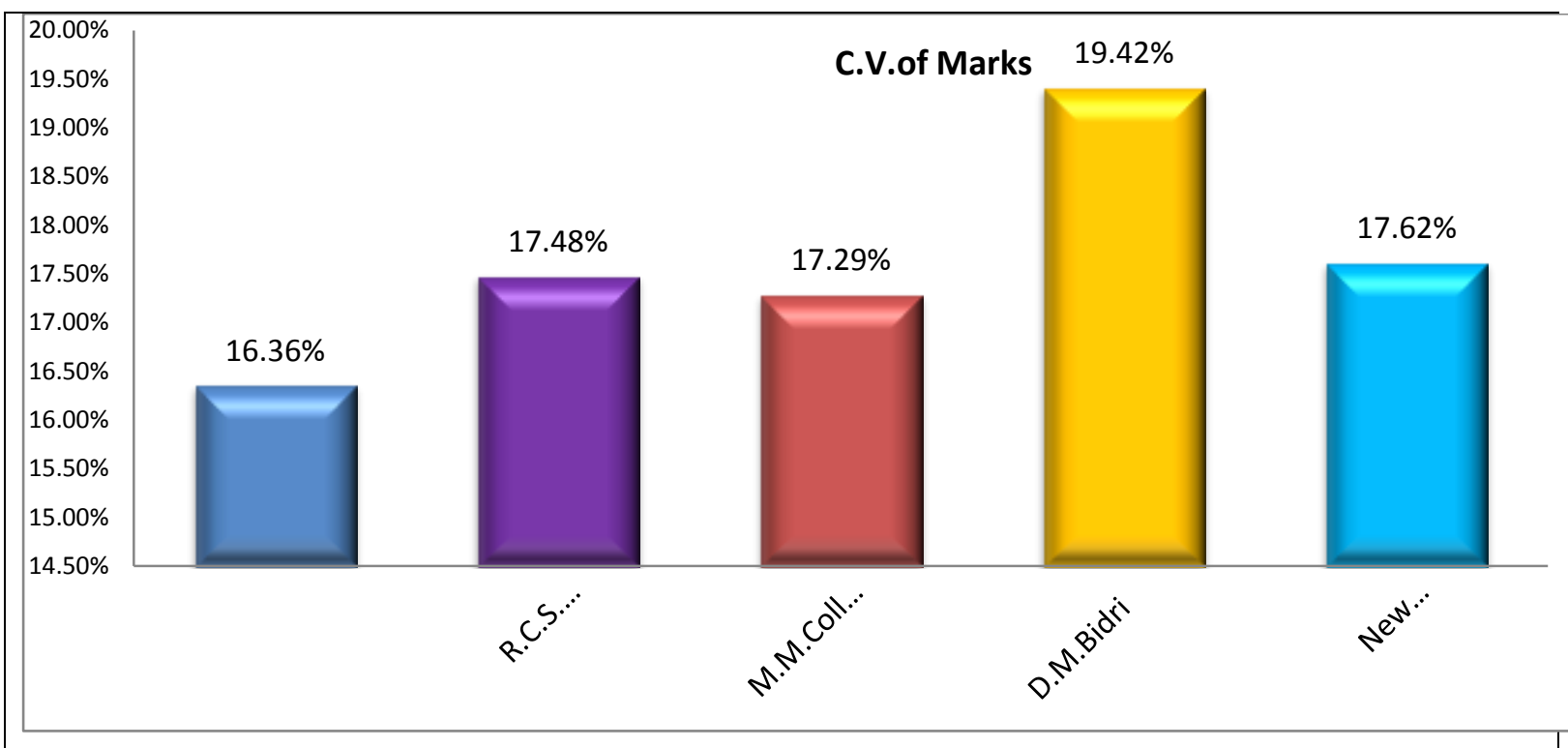

TESTING OF HYPOTHESIS

a) The study of association and colligation between employment and gender

Let the attribute A denote gender and $\mathrm{B}$ denote Employment.
$(\mathrm{AB})=$ Employed males $=379$;
$(\mathrm{A} \beta)=$ Unemployed males $=479$

$(\alpha \mathrm{B})=$ Employed females $=133 ;(\alpha \beta)=$ Unemployed females $=644$

\begin{tabular}{|c|c|}
\hline Coefficient of association & Coefficient of colligation \\
\hline$Q=\frac{\{(\mathrm{AB})(\alpha \beta)-(\mathrm{A} \beta)(\alpha \mathrm{B})\}}{\{(\mathrm{AB})(\alpha \beta)+(\mathrm{A} \beta)(\alpha \mathrm{B})\}}$ & $\mathrm{Y}=\sqrt{\frac{\{(\mathrm{AB})(\alpha \beta)-(\mathrm{A} \beta)(\alpha \mathrm{B})\}}{\{(\mathrm{AB})(\alpha \beta)+(\mathrm{A} \beta)(\alpha \mathrm{B})\}}}$ \\
$\mathrm{Q}=0.586026$ & $\mathrm{Y}=0.765523$ \\
& \\
\hline
\end{tabular}

b) The study of association and colligation between literacy and gender

Let the attribute $\mathrm{A}$ denote gender and $\mathrm{B}$ denote Literacy

$(\mathrm{AB})=$ Literate males $=663 ;(\mathrm{A} \beta)=$ Illiterate males $=57$

$(\alpha B)=$ Literate females $=688 ;(\alpha \beta)=$ Literate females $=101$

\begin{tabular}{|c|c|}
\hline Coefficient of association & Coefficient of colligation \\
\hline $\mathbf{Q}=\frac{\{(\mathbf{A B})(\boldsymbol{\alpha} \boldsymbol{\beta})-(\mathbf{A} \boldsymbol{\beta})(\boldsymbol{\alpha B})\}}{\{(\mathbf{A B})(\boldsymbol{\alpha})+(\mathbf{A})(\boldsymbol{\alpha B})\}}$ & $\mathrm{Y}=\sqrt{\frac{\{(A B)(\alpha \beta)-(A \beta)(\alpha B)\}}{\{(\mathrm{AB})(\alpha \beta)+(\mathrm{A} \beta)(\alpha \mathrm{B})\}}}$ \\
$\mathbf{Q}=0.2613$ & $\mathrm{Y}=0.5111$ \\
\hline
\end{tabular}

c) Chi-square test for independence of employment and Gender.

Let the attribute A denote gender and B denote Employment and the hypothesis are:.

$\mathrm{H}_{0}$ : The gender and employment are independent $\mathrm{V} / \mathrm{S}$

$\mathrm{H}_{1}$ : The gender and employment are not independent $\alpha=$ Level of significance $=5 \%$

$(a)=$ No. of employed males $=379 ;(b)=$ No. of unemployed males $=479$

(c) $=$ No. of employed females $=133 ;(d)=$ No. of unemployed females $=644$ 


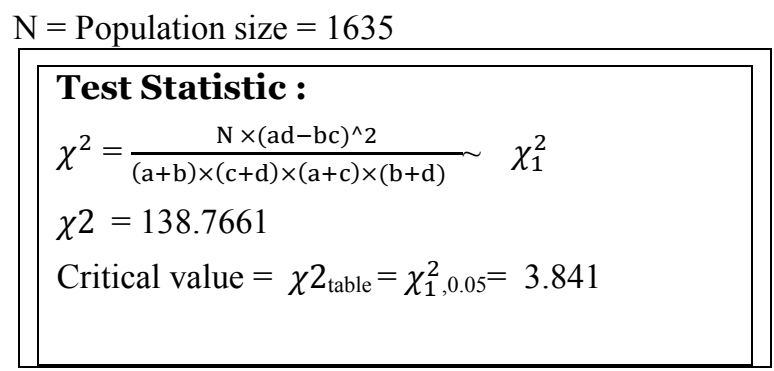

d) Chi-square test for independence of Literacy and Gender.

Let the attribute A denote gender and B denote Literacy and the hypothesis are :

$\mathrm{H}_{0}$ : The gender and Literate are independent $\mathrm{V} / \mathrm{S}$

$\mathrm{H}_{1}$ : The gender and Literate are not independent

$\alpha=$ Level of significance $=5 \%$

(a) $=$ No.of Literate males $=663 ;(b)=$ No. of Illiterate males $=57$

$(c)=$ No.of Literate females $=688 ;(d)=$ No. of Illiterate females $=101$

$\mathrm{N}=$ Population size $=1509$

$$
\begin{aligned}
& \text { Test Statistic : } \\
& \chi^{2}=\frac{\mathrm{N} \times(\mathrm{ad}-\mathrm{bc})^{\wedge} 2}{(\mathrm{a}+\mathrm{b}) \times(\mathrm{c}+\mathrm{d}) \times(\mathrm{a}+\mathrm{c}) \times(\mathrm{b}+\mathrm{d})} \sim \chi_{1}^{2} \\
& \chi 2=9.5807 \\
& \text { Critical value }=\chi 2_{\text {table }}=\chi_{1,0.05}^{2}=3.841
\end{aligned}
$$

\section{e) Test for proportion of users of mobile phone among Male in Rural and Urban}

\section{Areas:}

Let us denote first population is student in rural area and second population is student in urban area.

$\mathrm{P}_{1}=$ Proportion of male mobile user in rural area.

$\mathrm{P}_{2}=$ Proportion of male mobile users in urban area.

$\mathrm{n}_{1}=$ Sample size of student in rural $=101$

$\mathrm{n}_{2}=$ Sample size of student in urban $=44$

$\mathrm{p}_{1}$ : Sample proportion of male users of mobile phone in Rural $=0.8118$

$\mathrm{p}_{2}$ : Sample proportion of male users of mobile phone in Urban $=0.9779$
Hypothesis: $\mathrm{H}_{0}: \mathrm{P}_{1}=\mathrm{P}_{2}$
against
$\mathrm{H} 1: \mathrm{P}_{1} \neq \mathrm{P}_{2}$

\begin{tabular}{|l}
$\hat{p}=\left(\mathrm{n}_{1} \mathrm{p}_{1}+\mathrm{n}_{2} \mathrm{p}_{2}\right) /\left(\mathrm{n}_{1}+\mathrm{n}_{2}\right)$ \\
$\widehat{p}=0.8620$ and $\hat{q}=0.1379$ \\
$\quad$ The test statistic is, \\
$\mathrm{Z}_{\text {cal }}=\frac{\mathrm{P} 1-\mathrm{P} 2}{\sqrt{\hat{p} * \hat{q} *\left(\frac{1}{n 1}+\frac{1}{n 2}\right)}}=$ \\
$\mathrm{Z}_{\text {cal }}=-2.6558$ \\
Table value of $\mathrm{Z}$ is, $Z_{\frac{\alpha}{2}}=1.96$
\end{tabular}

f) Test for proportion of users of mobile phone among Female (Rural and Urban)

Population 1: students in rural areaand Population 2: student in urban area.

$\mathrm{P}_{1}=$ Proportion of female users of mobile phone in rural area.

P2=Proportion of female users of mobile phone in urban area

$\mathrm{n}_{1}=$ Sample size of student in rural $=147$ and $\mathrm{n}_{2}=$ Sample size of student in urban $=57$ 
$\mathrm{p}_{1}$ :Sample proportion of female users of mobile phone in Rural $=0.6870$

$\mathrm{p}_{2}$ : Sample proportion of female users of mobile phone in Urban $=0.9298$

Hypothesis: $\mathrm{H}_{0}: \mathrm{P}_{1}=\mathrm{P}_{2}$ against $\quad \mathrm{H}_{1}: \mathrm{P}_{1} \neq \mathrm{P}_{2}$

\section{Calculation:}

$\mid \hat{p}=\left(\mathrm{n}_{1} \mathrm{p}_{1}+\mathrm{n}_{2} \mathrm{p}_{2}\right) /\left(\mathrm{n}_{1}+\mathrm{n}_{2}\right)=0.7549$
and $\hat{q}=0.2450 \quad$ Under $\mathrm{H}_{0}$
The test statistic is,
\[ \mathrm{Z}_{\text {cal }}=\frac{\mathrm{P} 1-\mathrm{P} 2}{\sqrt{\hat{p} * \hat{q} *\left(\frac{1}{n 1}+\frac{1}{n 2}\right)}}=-7.5986 \]
Therefore table value of $\mathrm{Z}$ is, $Z_{\frac{\alpha}{2}}=1.96$

g) Test for proportion of genderwise users of mobile in Urban :

Population 1 = Male student's in urban area.

Population $2=$ Female students in urban area

Sample size of male $=\mathrm{n} 1=145$ and Sample size of female $=\mathrm{n} 2=204$

$\mathrm{p}_{1 \text { : }}$ Sample proportion of male users of mobile phone in urban $=0.2965$

$\mathrm{p}_{2 \text { : }}$ Sample proportion of female users of mobile phone in urban $=0.2598$

Let the level of significance $\alpha=5 \%$
Hypothesis:
$\mathrm{H}_{0}: \mathrm{P}_{1}=\mathrm{P}_{2} \quad$ against
$\mathrm{H}_{1}: \mathrm{P}_{1} \neq \mathrm{P}_{2}$

\section{Calculation:}

$$
\begin{gathered}
\hat{p}=\left(\mathrm{n}_{1} \mathrm{p}_{1}+\mathrm{n}_{2} \mathrm{p}_{2}\right) /\left(\mathrm{n}_{1}+\mathrm{n}_{2}\right)=0.2750 \\
\hat{q}=0.7249
\end{gathered}
$$

The test statistic is,

$$
\begin{aligned}
\mathrm{Z}_{\text {cal }}= & \frac{p 1-p 2}{\sqrt{\hat{p} * \hat{q} *\left(\frac{1}{n 1}+\frac{1}{n 2}\right)}}=0.7567 \\
& \text { Under } \mathrm{H}_{0}, \text { Critical value or }
\end{aligned}
$$

table value of $\mathrm{Z}$ is, $Z_{\frac{\alpha}{2}}=1.96$

h) Test for proportion of users of mobile in Rural (Male and Female)

Population 1: Male students in rural area.

Population 2: Female student's in rural area.

Sample size of male $=\mathrm{n}_{1}=145$

Sample size of female $=\mathrm{n}_{2}=204$

$\mathrm{p}_{1}$ : Sample proportion of male users of mobile phone in rural $=0.5655$

$\mathrm{p}_{2 \text { : }}$ Sample proportion of female users of mobile phone in rural $=0.4950$

Let the level of significance $\alpha=5 \%$
Hypothesis:
$\mathrm{H}_{0}: \mathrm{P}_{1}=\mathrm{P}_{2}$ against
$\mathrm{H}_{1}: \mathrm{P}_{1} \neq \mathrm{P}_{2}$ 


\section{Calculation}

\begin{tabular}{|c|}
\hline \\
\hline $\begin{aligned} & \hat{p}=\left(\mathrm{n}_{1} \mathrm{p}_{1}+\mathrm{n}_{2} \mathrm{p}_{2}\right) /\left(\mathrm{n}_{1}+\mathrm{n}_{2}\right) \\
& \hat{p}=0.5242 \quad \text { and } \quad \hat{q}=0.4757\end{aligned}$ \\
\hline Under $\mathrm{H}_{0}$ the test statistic is, \\
\hline \multirow{2}{*}{$\mathrm{Z}_{\mathrm{cal}}=\frac{p 1-p 2}{\sqrt{\hat{p} * \hat{q} *\left(\frac{1}{n 1}+\frac{1}{n 2}\right)}}=1.2997$} \\
\hline \\
\hline Critical value or table value of $Z$ is, $Z_{\frac{\alpha}{2}}=1.96$ \\
\hline
\end{tabular}

\section{i) Test for equality of regression coefficient.}

$\mathrm{y}=$ second year marks; $\mathrm{x}_{1}=$ first year marks; $\mathrm{x}_{2}=$ HSC marks; $\mathrm{x}_{3}=$ SSC marks;

The multiple regression equation is,

$\mathrm{y}=4.576133+0.775995 \mathrm{X}_{1}+0.088656 \mathrm{X}_{2}+0.0810196 \mathrm{X}_{3}$

ANOVA TABLE:

\begin{tabular}{|c|c|c|c|c|c|}
\hline & d. f. & s. s. & m. s. & F & P-Value \\
\hline Regression & 3 & 4779.343 & 1593.114 & 38.15648 & 0.00145 \\
\hline Residual & 56 & 2338.119 & 41.75213 & & \\
\hline Total & 59 & 7117.462 & & & \\
\hline $\mathrm{H}_{1}:$ At least one of the $\beta_{2}, \beta_{3}$, and $\beta 4$ does not equal to zero. \\
Level of significance $\alpha \%=5 \%$ \\
P-Value $=0.00145$ \\
P-Value $<0.05$,
\end{tabular}

\section{Test for Multiple Regression}

\begin{tabular}{|c|c|c|}
\hline & & Explanation \\
\hline Multiple R & 0.819448 & $\mathrm{R}=$ Square root of $R^{2}$ \\
\hline R-square & 0.671495 & $R^{2}$ \\
\hline Adj. R square & 0.653897 & Adjusted $R^{2}$ used if more than one X variable. \\
\hline Std. Error & 6.461589 & $\begin{array}{c}\text { This is the sample estimate of the standard } \\
\text { deviation of the error. }\end{array}$ \\
\hline Observations & 60 & $\begin{array}{c}\text { Number of observation used in the } \\
\text { regression(n) }\end{array}$ \\
\hline
\end{tabular}




\section{OVERALL CONCLUSION}

Our study shows that sixty two percent students are say that teacher performance is excellent and nearly all students are satisfies with quality of teaching.Sixty four percent students daily do study work regularly. The Percentage of using mobile phone in male students is higher than female students as well as nearly eighty percent male students are use android mobile.Ninty one percent students are satisfies with library facility as well as there is need to improve sports facility in colleges.Many students use whatsapp and facebook but rare students are known about googl+.There are many students having family annual income above one lakh.consistency in marks of students in vivekanand college is good as compared with other colleges.and there is positive association between employment and gender, employment and gender, literacy and gender and gender and employment are not independent.Literacy is dependent on gender.as well as the proportion of male users of mobile phone in rural is not equal to the proportion of male users of mobile phone in urban.But there is equal proportion of female which are uses mobile phone in rural and urban area.And the proportion of male users of mobile phone in urban is equal to proportion of female users of mobile phone in urban.The regression coefficients are significant.67.14 percent of the variation of second year marks around its mean is explained by the repressors first year marks, H.S.C marks and S.S.C marks.

\section{REFERENCES}

1. Lavin DE (1965) The prediction of academic performance. Russell Sage Foundation, New York

2. Macan TH, Shahani C, Dipboye RL, Phillips AP (1990) College students' time management: correlations with academic performance and stress. J Educ Psychol 82(4):760

3. Gašević D, Zouaq A, Janzen R (2013) "Choose your classmates, your GPA is at stake!" The association of cross-class social ties and academic performance. Am Behav Sci 57(10):1460-1479

4. Curcio G, Ferrara M, De Gennaro L (2006) Sleep loss, learning capacity and academic performance. Sleep Med Rev 10(5):323-337

5. Singh A, Uijtdewilligen L, Twisk JW, Van Mechelen W, Chinapaw MJ (2012) Physical activity and performance at school: a systematic review of the literature including $a$ methodological quality assessment. Arch Pediatr Adolesc Med 166(1):49-55

6. Van de Mortel TF et al. (2008) Faking it: social desirability response bias in self-report research. Aust J Adv Nurs 25(4):40

7. Junco $R$ (2013) Comparing actual and selfreported measures of Facebook use. Comput Hum Behav 29(3):626-631
8. Kumbasar E, Rommey AK, Batchelder WH (1994) Systematic biases in social perception. Am J Sociol 100(2):477-505

9. O'Connor KM, Gladstone E (2015) How social exclusion distorts social network perceptions. Soc Netw 40:123-128

10. Freeman LC (1992) Filling in the blanks: a theory of cognitive categories and the structure of social affiliation. Soc Psychol Q 55:118-127

11. Bernard HR, Killworth P, Kronenfeld D, Sailer $L$ (1984) The problem of informant accuracy: the validity of retrospective data. Annu Rev Anthropol 13(1):495-517

12. Astin, A. W. (1998). The changing American college student: Thirty-year trends, 1966-1996. The Review of Higher

13. Education, 21, 115-135. Brown, T. A. (2006). Confirmatory factor analysis for applied research. New York, NY:

14. Guilford.

15. 13.Deci, E., \& Ryan, R. M. (1985). Intrinsic motivation and self-determination in human behavior. New York, NY:

16. Plenum Press. DesJardines,

17. 14.S. L., Ahlburg, D. A., \& McCall, B. P. (2002). A temporal investigation of factors related to timely degree completion.

18. The Journal of Higher Education, 73, 555-581.

19. 15. Harackiewicz, J., Barron, K. E., Pintrich, P. R., Elliot, A. J. \& Thrash, T. M. (2002). Revision of achievement goal

20. theory: Necessary and illuminating. Journal of Educational Psychology, 94, 638-645. 